\title{
BMS-813160: A Potent CCR2 and CCR5 Dual Antagonist Selected as a Clinical Candidate
}

Robert J. Cherney, ${ }^{* \dagger}$ Prakash Anjanappa, ${ }^{\dagger}$ Kumaravel Selvakumar, ${ }^{\dagger}$ Douglas G. Batt, ${ }^{\dagger}$ Gregory D. Brown,,$^{\dagger}$ Anne V. Rose, ${ }^{\dagger}$ Ragini Vuppugalla, ${ }^{\dagger}$ Jing Chen, ${ }^{\dagger}$ Jian Pang, ${ }^{\dagger}$ Songmei Xu, ${ }^{\dagger}$ Melissa

Yarde, ${ }^{\dagger}$ Andrew J. Tebben, ${ }^{\dagger}$ Venkatram Reddy Paidi, ${ }^{\neq}$Mary Ellen Cvijic, ${ }^{\dagger}$ Arvind Mathur, ${ }^{\dagger}$ Joel C. Barrish, ${ }^{\dagger}$ Sandhya Mandlekar, ${ }^{\dagger}$ Qihong Zhao, ${ }^{\dagger}$ and Percy H. Carter ${ }^{\dagger}$

${ }^{\dagger}$ Bristol Myers Squibb Company, Research and Early Development, Princeton, New Jersey 08540-4000, United States

\#Biocon Bristol Myers Squibb Research and Development Center, Bangalore 560099, India

\section{Supporting Information}

\section{$\underline{\text { Table of Content }}$}

General

S1

HPLC conditions

S2

Procedures and characterization data for compounds 3 and 5-7

S2-S4

TG peritonitis mouse model

S4

Human CXCR2 binding assay

S4-S5

Human liver microsome $\mathrm{t}_{1 / 2}$ assay

S5

References

S5

\section{Experimental Procedures:}

All experiments involving animals were performed in accordance with institutional guidelines as defined by the Institutional Animal Care and Use Committee for U.S. institutions. Assays in Table 1 were performed as previously described. ${ }^{1}$ Assays in Table 2 were performed in an analogous manner to the following literature procedures: CCR 1 binding assay, ${ }^{2} \mathrm{CCR} 4$ binding assay, ${ }^{3}$ CXCR 2 binding assay (see description below), human liver microsome (see description below), hERG patch clamp, ${ }^{4}$ protein binding (human, mouse, and rat), ${ }^{5}$ and PAMPA. ${ }^{1}$ The mouse CCR2 binding assay (mouse CCR2 Bnd, Table 2) was run analogously to the human CCR2 binding assay except mouse $\left[{ }^{125} \mathrm{I}\right]-\mathrm{CCL} 2$ was used instead of human $\left[{ }^{125} \mathrm{I}\right]-\mathrm{CCL} 2$. Anhydrous solvents from commercial sources were used for all reactions. All other reagents and solvents were reagent grade and used as received from commercial sources. Column chromatography was performed on a Teledyne ISCO system with commercial silica gel columns. Final compounds were purified by reversed phase high-performance liquid chromatography (HPLC) as indicated. ${ }^{1} \mathrm{H}$ NMR were obtained on Bruker or JEOL spectrometers (operating at $400 \mathrm{MHz}$ or $600 \mathrm{MHz}$ ), and the signals are reported in ppm relative to TMS (NMR abbreviations: $\mathrm{s}=$ singlet, $\mathrm{br} \mathrm{s}=$ broad singlet, $\mathrm{d}=$ doublet, $\mathrm{dd}=$ doublet of doublets, $\mathrm{t}=$ triplet, $\mathrm{q}$ $=$ quartet, quin $=$ quintuplet, $\mathrm{sep}=$ septet, $\mathrm{m}=$ multiplet $)$. All mass spectra were recorded using electrospray ionization (ESMS) in the positive (pos) mode unless otherwise noted. All assayed compounds have a purity of $>90 \%$ as assessed by analytical HPLC. 


\section{HPLC Conditions:}

Method A: (analytical)

Column: YMC ODS $\mathrm{C}_{18}(4.6$ x $50 \mathrm{~mm}, 3 \mu \mathrm{m})$; mobile phase A: 10:90 MeOH:water with $0.2 \% \mathrm{H}_{3} \mathrm{PO}_{4}$; mobile phase B: 90:10 MeOH:water with $0.2 \% \mathrm{H}_{3} \mathrm{PO}_{4}$; flow rate $2.5 \mathrm{~mL} / \mathrm{min}$; gradient $0 \%$ B to $100 \%$ B over 8 min; wavelenth $220 \mathrm{~nm}$.

Method B: (preparative)

Column: Phenomenex Luna $\mathrm{C}_{18}(21.2 \times 100 \mathrm{~mm}, 5 \mu \mathrm{m})$; mobile phase A: 10:90 $\mathrm{MeOH}$ :water with 0.1\% TFA; mobile phase B: 90:10 MeOH:water with 0.1\% TFA; flow rate 20 $\mathrm{mL} / \mathrm{min}$; gradient $0 \% \mathrm{~B}$ to $100 \%$ B over $12 \mathrm{~min}$; wavelenth $220 \mathrm{~nm}$.

$N-((1 R, 2 S, 5 R)-2-((S)-3-((7-(t e r t-b u t y l)$ pyrazolo[1,5-a][1,3,5]triazin-4-yl)amino)-2oxopyrrolidin-1-yl)-5-(tert-butylamino)cyclohexyl)acetamide (Compound 3)

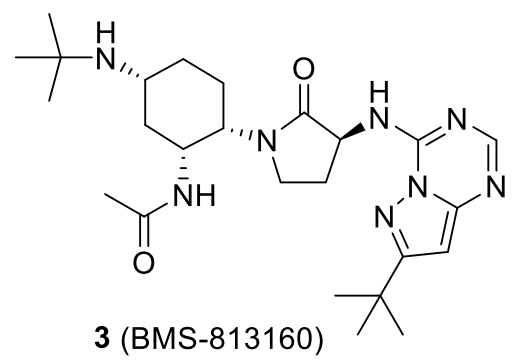

Step 1: 1-(ethoxycarbonyl)-3-(3-(tert-butyl)-1H-pyrazol-5-yl)-thiourea 5<smiles>CCOC(=O)NC(=S)Nc1cc(C(C)(C)C)n[nH]1</smiles>

To a solution of 3-amino-5-tert-butyl pyrazole $4(1.00 \mathrm{~g}, 7.18 \mathrm{mmol})$ in ethyl acetate $(10 \mathrm{~mL})$ and benzene $(50 \mathrm{~mL})$ at $5{ }^{\circ} \mathrm{C}$ was added a solution of ethoxycarbonyl isothiocyanate $(0.942 \mathrm{~g}, 7.18$ $\mathrm{mmol})$ in benzene $(10 \mathrm{~mL})$ dropwise. $^{6}$ After the addition, the reaction was warmed to $\mathrm{rt}$ and was stirred for $16 \mathrm{~h}$. This mixture was concentrated. The resulting residue was purified by silica gel chromatography using 0-40\% ethyl acetate/petroleum ether to give 1-(ethoxycarbonyl)-3-(3-(tertbutyl)-1H-pyrazol-5-yl)-thiourea $5(1.75 \mathrm{~g}, 90 \%)$ as an off-white solid: ${ }^{1} \mathrm{H}$ NMR (400 MHz, DMSO-d $\left.d_{6}\right) 12.43(\mathrm{~s}, 1 \mathrm{H}), 11.97(\mathrm{~s}, 1 \mathrm{H}), 11.24(\mathrm{~s}, 1 \mathrm{H}), 6.83(\mathrm{~d}, \mathrm{~J}=2.0 \mathrm{~Hz}, 1 \mathrm{H}), 4.22$ (q, J=7.0 Hz, $2 \mathrm{H}), 1.30$ - $1.24(\mathrm{~m}, 13 \mathrm{H})$; LCMS calculated for $\mathrm{C}_{11} \mathrm{H}_{18} \mathrm{~N}_{4} \mathrm{O}_{2} \mathrm{~S}[\mathrm{M}+\mathrm{H}]^{+}: \mathrm{m} / \mathrm{z}=271.1$, found: 271.1 .

Step 2: 7-(tert-butyl)-2-thioxo-2,3-dihydropyrazolo[1,5-a][1,3,5]triazin-4(1H)-one 6 


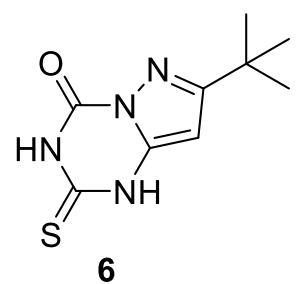

Compound 5 (1.40 g, $5.18 \mathrm{mmol})$ was dissolved in $2 \mathrm{~N} \mathrm{NaOH}(25 \mathrm{~mL}, 50 \mathrm{mmol})$ and stirred at $\mathrm{rt}$ for $2 \mathrm{~h}$. The solution was cooled and acidified to $\mathrm{pH}=1$ by the addition of $2 \mathrm{~N} \mathrm{H}_{2} \mathrm{SO}_{4}$. The solid product was collected by filtration and dried to give 7-(tert-butyl)-2-thioxo-2,3dihydropyrazolo[1,5-a][1,3,5]triazin-4(1H)-one 6 (1.1 g, 95\%): ${ }^{1} \mathrm{H}$ NMR (400 MHz, DMSO- $\left.d_{6}\right)$ $\delta 13.38$ (br s, $1 \mathrm{H}), 12.75$ (br.s, $1 \mathrm{H}), 5.84$ (s, 1H), 1.34 (s, 9H); LCMS calculated for $\mathrm{C}_{9} \mathrm{H}_{12} \mathrm{~N}_{4} \mathrm{OS}$ $[\mathrm{M}+\mathrm{H}]^{+}: \mathrm{m} / \mathrm{z}=225.1$, found: 225.2 .

Step 3: 7 -(tert-butyl)pyrazolo[1,5-a][1,3,5]triazin-4(3H)-one 7<smiles>CC(C)(C)c1cc2nc[nH]c(=O)n2n1</smiles>

7

To compound 6 (536 mg, $2.39 \mathrm{mmol})$ in methanol (15 mL) was added concentrated (29\%) ammonium hydroxide solution $(10 \mathrm{~mL})$ and Raney nickel $(500 \mathrm{mg})$. The reaction mixture was heated at $100{ }^{\circ} \mathrm{C}$ for $4 \mathrm{~h}$. After cooling, the mixture was filtered and the filtrate was concentrated. The resulting residue was purified by silica gel chromatography $(0-5 \%$ $\mathrm{MeOH} / \mathrm{DCM})$ to give 7-(tert-butyl)pyrazolo[1,5-a][1,3,5]triazin-4(3H)-one $7(230 \mathrm{mg}, 50 \%)$ as an off-white solid: ${ }^{1} \mathrm{H}$ NMR (400 MHz, DMSO- $\left.d_{6}\right) \delta 12.44$ (br s, 1H), $7.96(\mathrm{~s}, 1 \mathrm{H}), 6.50(\mathrm{~s}, 1 \mathrm{H})$, 1.32 - 1.25 (m, 9H); LCMS calculated for $\mathrm{C}_{9} \mathrm{H}_{12} \mathrm{~N}_{4} \mathrm{O}[\mathrm{M}+\mathrm{H}]^{+}: \mathrm{m} / \mathrm{z}=193.1$, found: 193.1 .

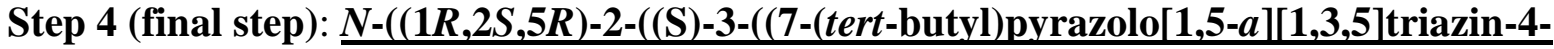
yl)amino)-2-oxopyrrolidin-1-yl)-5-(tert-butylamino)cyclohexyl)acetamide (Compound 3)

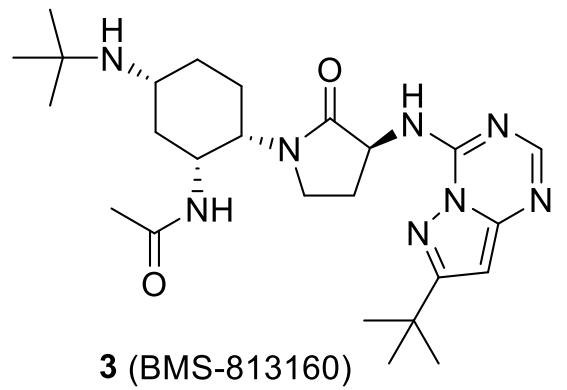

7-tert-butylpyrazolo[1,5-a][1,3,5]triazin-4-ol 7 (300 mg, $1.6 \mathrm{mmol})$ was dissolved in $\mathrm{POCl}_{3}(7.3$ $\mathrm{mL}, 78 \mathrm{mmol}$ ) and heated to reflux overnight. After cooling, the $\mathrm{POCl}_{3}$ was removed by rotary 
evaporation. This was dissolved in DCM and concentrated (X3). The resulting residue was taken up in DCM and washed with saturated $\mathrm{NaHCO}_{3}$ solution (aq). The organic layer was dried $\left(\mathrm{MgSO}_{4}\right)$, filtered, and concentrated to give crude 7-tert-butyl-4-chloropyrazolo[1,5-

a] $[1,3,5]$ triazine $8(338 \mathrm{mg}, 1.6 \mathrm{mmol}): \mathrm{LCMS}=211.1[\mathrm{M}+\mathrm{H}]^{+}$, a portion of which was used in the following. $N-((1 R, 2 S, 5 R)-2-((\mathrm{S})-3$-amino-2-oxopyrrolidin-1-yl)-5-(tert-

butylamino)cyclohexyl)-acetamide $9^{7}(230 \mathrm{mg}, 0.74 \mathrm{mmol})$ was dissolved in 2-propanol $(3 \mathrm{~mL})$ and triethylamine $(0.26 \mathrm{~mL}, 1.85 \mathrm{mmol})$. This solution was added to crude 7-tert-butyl-4chloropyrazolo[1,5-a][1,3,5]triazine $8(130 \mathrm{mg}, 0.62 \mathrm{mmol})$ from above. After $3 \mathrm{~h}$, the solution was concentrated. This crude material was partitioned between water containing AcOH $(0.085$ $\mathrm{mL}, 1.48 \mathrm{mmol}$ ) and $\mathrm{Et}_{2} \mathrm{O}$. The aqueous layer (containing product) was lyophilized overnight. The resulting residue was purified by preparative reverse phase HPLC (Method B, product retention time $=8.8 \mathrm{~min}$ ). The fractions containing product were concentrated. This residue was dissolved in DCM and a saturated $\mathrm{Na}_{2} \mathrm{CO}_{3}$ solution (aq) was added. The organic layer was dried $\left(\mathrm{Na}_{2} \mathrm{SO}_{4}\right)$, filtered, and concentrated to give free base title compound $N$ - $((1 R, 2 S, 5 R)-5$ - $($ tertbutylamino)-2-((S)-3-(7-tert-butylpyrazolo[1,5-a][1,3,5]triazin-4-ylamino)-2-oxopyrrolidin-1yl)cyclohexyl)acetamide 3 (45.6 mg, $0.094 \mathrm{mmol}, 15 \%)$ : LCMS m/z = 485.4 [M+H] ${ }^{+} ;{ }^{1} \mathrm{H}$ NMR $\left(600 \mathrm{MHz}, \mathrm{DMSO}-d_{6}\right) \delta 1.04(\mathrm{~s}, 9 \mathrm{H}), 1.34(\mathrm{~s}, 9 \mathrm{H}), 1.58(\mathrm{~m}, 3 \mathrm{H}), 1.64(\mathrm{~m}, 2 \mathrm{H}), 1.81(\mathrm{~s}, 3 \mathrm{H}), 2.05$ $(\mathrm{m}, 1 \mathrm{H}), 2.12(\mathrm{~m}, 1 \mathrm{H}), 2.36(\mathrm{~m}, 1 \mathrm{H}), 2.93($ br s, $1 \mathrm{H}), 3.48(\mathrm{~m}, 2 \mathrm{H}), 3.84(\mathrm{~m}, 1 \mathrm{H}), 4.26($ br s, $1 \mathrm{H})$, $4.86(\mathrm{t}, \mathrm{J}=8.9 \mathrm{~Hz}, 1 \mathrm{H}), 6.39(\mathrm{~s}, 1 \mathrm{H}), 8.07(\mathrm{~s}, 1 \mathrm{H}), 8.94(\mathrm{br} \mathrm{s}, 1 \mathrm{H}) ;{ }^{13} \mathrm{C}$ NMR $(125.8 \mathrm{MHz}$, DMSO- $\left.d_{6}\right) \delta 21.3,23.3,25.9,29.3,30.0,32.2,32.6,35.5,43.1,46.5,47.7,50.7,51.7,52.5,92.3$, 148.7, 148.8, 152.9, 167.3, 168.5, 171.2; HRMS calcd for $\mathrm{C}_{25} \mathrm{H}_{40} \mathrm{~N}_{8} \mathrm{O}_{2}[\mathrm{M}+\mathrm{H}]^{+} 485.3347$, found 485.3346; Analytical HPLC $t_{R}=4.4 \min ($ Method A).

Thioglycollate (TG)-induced peritonitis mouse model $^{8}$ (Figure 3). Six to eight C57BL/6 male mice (Taconic Laboratories), age 9-11 weeks, were treated with compound (vehicle was $0.02 \mathrm{~N}$ $\mathrm{HCl}$ ) by gavage one hour prior to thioglycollate challenge. Thioglycollate (Hardy Diagnostics) was administered IP, $1 \mathrm{~mL}$ per mouse. For the 48 hour model, mice were dosed by gavage, BID, for 2 days. On day 3, serum was collected for compound exposure, and the mice were sacrificed by carbon dioxide overdose. The peritoneal cavity was injected with $5 \mathrm{~mL}$ phosphate-buffered saline containing $0.01 \mathrm{M}$ EDTA and $10 \%$ fetal bovine serum. The peritoneal cavity was massaged 15 times, and then the contents collected to retrieve the inflammatory cells. The typical retrieval volume was 4.2-4.5 mL. Total cell counts were determined on a CASY counter, and cytospin slides were made of the lavaged cells. The slides were stained with Diff-Quik, and differential cell counts were performed by manually counting 200 cells per slide. The total cell number of each inflammatory cell type was calculated for each mouse. The average and standard error of the mean (SEM) for recruited monocytes and macrophages for each group was plotted.

Human CXCR2 binding assay (CXCR2 Bnd, Table 2). The human CXCR2 ligand binding assay was established with human overexpressed pEAK cells (Perkin Elmer Membrane Preparation Cat.\# RPHCX2M) using human [ $\left.{ }^{125} \mathrm{I}\right]$-Interlukin-8 as the tracer ligand (Perkin Elmer, NEX277). $10 \mu \mathrm{g}$ of membrane per well was incubated with $\left[{ }^{125} \mathrm{I}\right]$-Interleukin-8 (2000 $\mathrm{Ci} / \mathrm{mmol}, 0.162 \mathrm{nM}$ ) and $200 \mathrm{nM}$ unlabeled ligand in a total volume of $0.1 \mathrm{~mL}$ for $90 \mathrm{~min}$ at 25 ${ }^{\circ} \mathrm{C}$. The mixture was filtered over GF/C (S\&S) filters (presoaked in $0.5 \% \mathrm{PEI}$ ) and the filters were washed 5x with $1 \mathrm{~mL}$ ice-cold $50 \mathrm{mM}$ HEPES-KOH (pH 7.4), $0.5 \mathrm{M} \mathrm{NaCl}$ and $0.1 \%$ BSA. After washing, the plate was air-dried for 60 minutes at room temperature. This was followed by adding $25 \mu \mathrm{L}$ of Microscint 20 into each well. The plate was sealed and counted on the 
Trilux for $1 \mathrm{~min}$. All conditions were tested in duplicate. The $\mathrm{IC}_{50}$ is defined as the concentration of competing cold ligand required to reduce specific binding by $50 \%$.

Method for liver microsome $\mathbf{t}_{1 / 2}$ assay (LM t $\mathbf{t}_{1 / 2}$, Table 2 ). Using compound 3 as an example, compound $3(0.5 \mu \mathrm{M})$ was incubated with liver microsomes $(1 \mathrm{mg} / \mathrm{mL}$ final concentration) fortified with NADPH $(1 \mathrm{mM})$ at $37^{\circ} \mathrm{C}$. Metabolic reactions were terminated after $0,5,10,15$, 30 , and 45 minutes by transferring an aliquot of the reaction mixtures into an acetonitrile quench solution to denature microsomal enzymes. The relative amount of the compound 3 remaining in the reaction mixtures at each time point was quantified using LC-MS/MS analysis. The results for each time point were normalized to the relative amount of compound $\mathbf{3}$ in the 0 -minute sample and expressed as percent remaining. The elimination rate constant $\left(\mathrm{k}_{\mathrm{el}}\right)$ was determined using a linear regression model (natural logarithm of \% remaining versus time), and metabolic half-life was calculated $\left(0.693 / \mathrm{k}_{\mathrm{el}}\right)$.

\section{References:}

(1) Carter, P. H.; Cherney, R. J. N-((1R,2S,5R)-5-(tert-butylamino)-2-((S)-3-(7-tertbutylpyrazolo[1,5-a] [1,3,5] triazin-4-ylamino)- 2-oxopyrrolidin-1-yl)cyclohexyl) acetamide, a dual modulator of chemokine receptor activity, crystalline forms and processes. Patent no. US 8,618,101 B2, December 31, 2013.

(2) Cavallaro, C. L.; Briceno, S.; Chen, J.; Cvijic, M. E.; Davies, P.; Hynes, J., Jr.; Liu, R. Q.; Mandlekar, S.; Rose, A. V.; Tebben, A. J.; Van Kirk, K.; Watson, A.; Wu, H.; Yang, G.; Carter, P. H. Discovery and lead optimization of a novel series of CC chemokine receptor 1 (CCR1)-selective piperidine antagonists via parallel synthesis. J. Med. Chem. 2012, 55, 9643-9653.

(3) Viney, J. M.; Andrew, D. P.; Phillips, R. M.; Meiser, A.; Patel, P.; Lennartz-Walker, M.; Cousins, D. J.; Barton, N. P.; Hall, D. A.; Pease, J. E. Distinct conformations of the chemokine receptor CCR4 with implications for its targeting in allergy. J. Immunol. 2014, 192, 3419-3427.

(4) Zhou, Z.; Gong, Q.; Ye, B.; Fan, Z.; Makielski, J. C.; Robertson, G. A.; January, C. T. Properties of hERG channels stably expressed in HEK 293 cells studied at physiological temperature. Biophys. J. 1998, 74, 230-241.

(5) Waters, N. J.; Jones, R.; Williams, G.; Sohal, B. Validation of a rapid equilibrium dialysis approach for the measurement of plasma protein binding. J. Pharm. Sci. 2008, 97, 4586-4595.

(6) Kobe, J.; Robins, R. K.; O'Brien, D. E. The synthesis and chemical reactions of certain pyrazolo[1,5-a]-1,3,5-triazines. J. Heterocycl. Chem. 1974, 11, 199-204.

(7) Yang, M. G.; Xiao, Z.; Zhao, R.; Tebben, A. J.; Wang, B.; Cherney, R. J.; Batt, D. G.; Brown, G. D.; Cvijic, M. E.; Duncia, J. V.; Galella, M.; Gardner, D. S.; Khandelwal, P.; Malley, M. F.; Pang, J.; Rose, A. V.; Santella, J. B., 3rd; Sarjeant, A. A.; Xu, S.; Mathur, A.; Mandlekar, S.; Vuppugalla, R.; Zhao, Q.; Carter, P. H. Discovery of BMS-753426: A potent orally bioavailable antagonist of CC chemokine receptor 2. ACS Med. Chem. Lett. 2021, 12, 969-975.

(8) Melnicoff, M. J.; Horan, P. K.; Morahan, P. S. Kinetics of changes in peritoneal cell populations following acute inflammation. Cell. Immunol. 1989, 118, 178-191. 